\title{
INFLUENCE OF SCANNING SPEED ON THE INTERMETALLIC PRODUCED IN-SITU IN LASER-METAL-DEPOSITED TiC/Ti6Al4V COMPOSITE
}

\author{
VPLIV HITROSTI SKENIRANJA NA INTERMETALNO ZLITINO \\ IZDELANO IN-SITU Z LASERSKO DEPOZICIJO TiC/Ti6Al4V \\ KOMPOZITA
}

\author{
Rasheedat Modupe Mahamood ${ }^{1,2}$, Esther Titilayo Akinlabi ${ }^{1}$ \\ ${ }^{1}$ University of Johannesburg, Department of Mechanical Engineering Science, Auckland Park, Kingsway Campus, \\ Johannesburg 2006, South Africa \\ ${ }^{2}$ University of Ilorin, Department of Mechanical Engineering, Tanke road 23400003, Nigeria \\ mahamoodmr2009@gmail.com
}

Prejem rokopisa - received: 2016-05-29; sprejem za objavo - accepted for publication: 2016-06-28

doi:10.17222/mit.2016.096

\begin{abstract}
The effect of scanning speed on titanium aluminide $\mathrm{Ti}_{3} \mathrm{Al}$ produced in-situ during laser metal deposited $\mathrm{TiC} / \mathrm{Ti}$ Al4 $\mathrm{V}$ has been investigated and its effect on the microhardness and wear-resistance properties has been studied. In this study, the titanium alloy Ti6Al4V (an important aerospace alloy) was deposited in combination with titanium carbide TiC using a laser metal deposition process. The laser power was maintained at $3.2 \mathrm{~kW}$ throughout the deposition process. The powder flow rate and the gas flow rate were also kept at constant values of $2.88 \mathrm{~g} / \mathrm{min}$ and $21 / \mathrm{min}$, respectively. The scanning speed was varied between 0.015 and $0.105 \mathrm{~m} / \mathrm{s}$, and the influence of the scanning speed on the titanium aluminide $\left(\mathrm{Ti}_{3} \mathrm{Al}\right)$ produced in-situ was studied, and its effect on the wear resistance behaviour was also investigated. The study revealed that as the scanning speed was initially increased, the $\mathrm{Ti}_{3} \mathrm{Al}$ produced in-situ was found to increase and the wear resistance was found to improve. As the scanning speed was further increased beyond $0.06 \mathrm{~m} / \mathrm{s}$, the $\mathrm{Ti}_{3} \mathrm{Al}$ produced and the wear resistance were found to decrease.

Keywords: laser metal deposition process, microhardness, microstructure, titanium alloy, $\mathrm{Ti}_{3} \mathrm{Al}$, wear resistance
\end{abstract}

Preiskovan je bil vpliv hitrosti skeniranja na in-situ nastanek titanovega aluminida - Ti3Al, izdelanega med lasersko depozicijo TiC/Ti6Al4V ter proučevan je bil njen vpliv na mikrotrdoto in obrabne lastnosti. V tej študiji je bila titanova zlitina -Ti6Al4V (pomembna zlitina za letalstvo), nanešena v kombinaciji s titanovim karbidom - TiC, s pomočjo postopka laserskega nanašanja. Med postopkom nanašanja je bila vzdrževana moč laserja pri $3,2 \mathrm{~kW}$. Hitrosti toka prahu in toka plina sta bili zadržani pri konstantnih vrednostih $2,88 \mathrm{~g} / \mathrm{min}$ in $21 / \mathrm{min}$. Hitrost skeniranja se je spreminjala med 0,015 in $0,105 \mathrm{~m} / \mathrm{s}$. Studiran je bil vpliv hitrosti skeniranja na in-situ nastanek titanovega aluminide $\left(\mathrm{Ti}_{3} \mathrm{Al}\right)$ ter njen vpliv na obnašanje pri obrabi. Studija je odkrila, da je začetno povečanje hitrosti skeniranja povečalo in-situ nastajanje $\mathrm{Ti}_{3} \mathrm{Al}$, povečala se je tudi odpornost proti obrabi. Pri nadaljnjem povečevanju hitrosti skeniranja nad $0,06 \mathrm{~m} / \mathrm{s}$, je bilo ugotovljeno zmanjšanje nastajanja $\mathrm{Ti}_{3} \mathrm{Al}_{\text {in }}$ zmanjšanje odpornosti proti obrabi.

Ključne besede: postopek nanašanja kovine z laserjem, mikrotrdota, mikrostruktura, titanova zlitina, $\mathrm{Ti}_{3} \mathrm{Al}$, odpornost proti obrabi

\section{INTRODUCTION}

Ti6Al4V is widely used in industry because of its good combination of properties, such as high specific strength, low density and good corrosion resistance. However, Ti6Al4V has a poor wear-resistance property owing to its chemical behaviour that tends to reduce its further application.1,2 The surface property of the material can be modified in order to improve its wear resistance property. Different surface-treatment methods have been applied to titanium alloys in order to improve their wear-resistance property in the literature, such as physical vapour deposition, chemical vapour deposition and sol-gel methods., ${ }^{3,4}$ The laser metal deposition (LMD) process, an additive manufacturing technique, is the most advantageous of all the methods. This is because a complex shaped part can be produced with the desired surface properties directly from the three-dimen- sional (3D) computer-aided-design (CAD) model of the part by adding material layer by layer. ${ }^{5}$ LMD also has the flexibility to handle more than one material simultaneously, thereby making it possible to make a part with composite or functionally graded materials.

An intermetallic compound of $\mathrm{Ti}_{3} \mathrm{Al}$ has been found to have several advantages, such as higher elastic modulus, lower density, better mechanical properties at elevated temperatures and higher oxidation resistance because it forms a surface-passivated alumina layer. ${ }^{1}$ The intermetallic-matrix composites (IMCs) with ceramic particles are also found to possess higher specific strength, improved toughness, and high-temperature strength retention. ${ }^{6,7}$ A lot of studies have been conducted in the literature on intermetallic compound reinforced ceramic composite as a result of the improved properties they offer. ${ }^{8-10}$ In this work, a composite of TiC/Ti6Al4V was produced and $\mathrm{Ti}_{3} \mathrm{Al}$ was formed 
in-situ. The effect of scanning speed on the quantity of the $\mathrm{Ti}_{3} \mathrm{Al}$ formed in-situ was studied and its influence on the microhardness and the wear-resistance properties was investigated in detail and reported.

\section{EXPERIMENTAL PART}

The powders used in this study are titanium alloy Ti6Al4V power of $99.6 \%$ purity, supplied by VSMPO-AVISMA Corporation, Russia and TiC powder of $99.5 \%$ purity and it was supplied by F. J. Brodmann and Co., L. L. C. Louisiana. The substrate material used is a $99.6 \%$ pure Ti6Al4V, $(72 \times 72 \times 5) \mathrm{mm}$ sheet. The chemical compositions of the powders and the substrate are listed in Table 1. The TiC powder is of particle size range below $60 \mu \mathrm{m}$ and the Ti6Al4V powder is of particle size range between $150 \mu \mathrm{m}$ and $200 \mu \mathrm{m}$. The substrate was sandblasted and then degreased using acetone before the deposition processes: this is to improve the laser-energy absorption. A Kuka robot was used for the laser metal deposition experiment. The 4.0-kW Nd-YAG laser (Rofin Sinar) was attached to the robot's end effector with two coaxial powder-delivery nozzles. The experimental set-up also consists of a glove box, a table and a two-hoppers powder feeder. The experimental set-up is shown in Figure 1. The two powders were put in a separate hopper of the powder feeder and

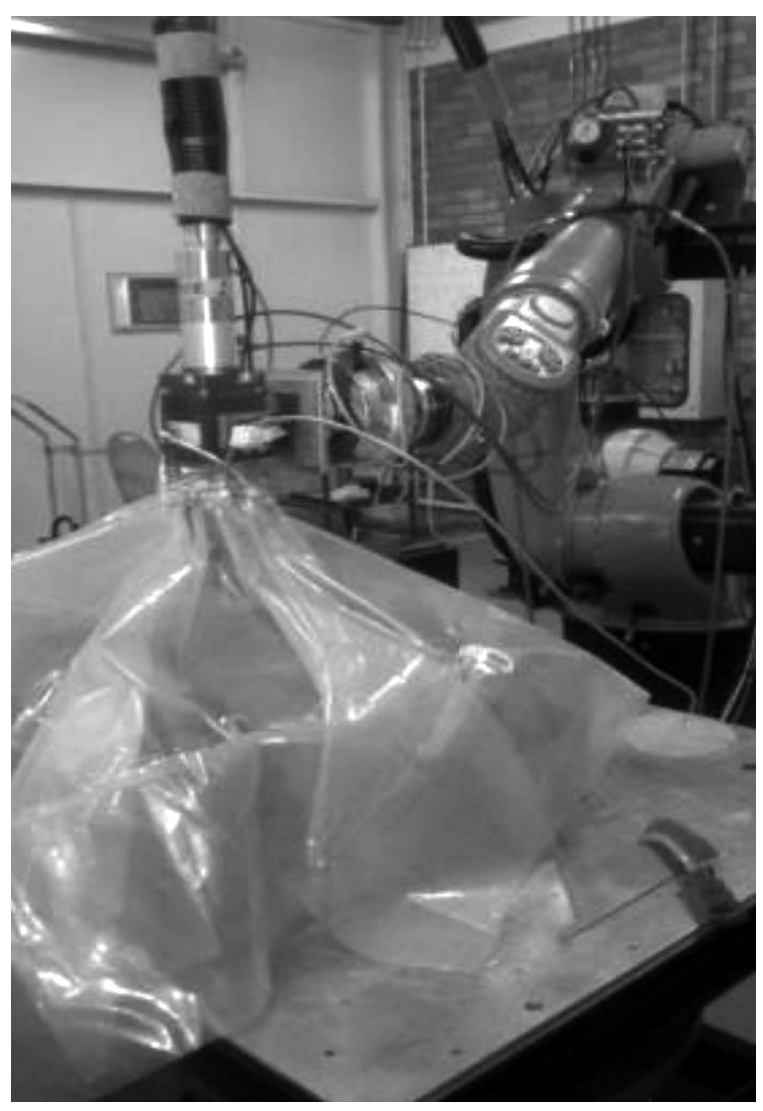

Figure 1: Experimental set-up Slika 1: Eksperimentalni sestav the powder flow rates were set to give $50 \mathrm{~W} \%$ of TiC powder and $50 \mathrm{~W} \%$ Ti6Al4V powder for the composite. Multiple tracks were produced at $50 \%$ overlap. The laser power was set at $3.2 \mathrm{~kW}$ and maintained at that value throughout the deposition process. The powder flow rate and the gas flow rate were set and kept at constant values of $2.88 \mathrm{~g} / \mathrm{min}$ and $2 \mathrm{~L} / \mathrm{min}$ respectively. The scanning speeds were varied between 0.015 and $0.105 \mathrm{~m} / \mathrm{s}$. Argon gas was used to keep the oxygen level in the glove box below $10 \mathrm{ppm}$ during the deposition process to prevent the atmospheric oxygen and nitrogen from contaminating the deposits. The laser metal deposition process was achieved by feeding the powders through the coaxial nozzles into the melt pool that was created on the substrate using the laser beam that forms the composite after the solidification of the melt pool. See Figure 2 for the schematic of the laser metal deposition process.

Scanning electron microscopy (SEM), X-ray energydispersive spectroscopy (EDS) analysis, and X-ray diffraction (XRD) were used for the microstructures and phase analyses of the deposited samples respectively. Samples for the SEM and microhardness were sectioned laterally, mounted in hot resin, ground and polished using the standard metallographic techniques according to the ASTM E3 - 11, standard. ${ }^{11}$ The SEM samples were etched using Kroll's reagent. The Kroll's reagent consists of $100 \mathrm{~mL}$ of water with $2 \mathrm{~mL}$ of hydrofluoric acid and $4 \mathrm{~mL}$ of nitric acid. The microhardness measurements were conducted using a Vickers indenter under a 300-g load and a dwell time of $15 \mathrm{~s}$ according to the ASTM E384 - 11e1 (2011) standard. ${ }^{12}$ The wear tests were performed under dry conditions (no lubrication) using a ball-on-disk arrangement on a Cert tribotester. A Tungsten Carbide ball of $10 \mathrm{~mm}$ diameter was used at a load of $25 \mathrm{~N}$, reciprocating frequency of $20 \mathrm{~Hz}$ and at a sliding distance of $2000 \mathrm{~mm}$. The wear test was

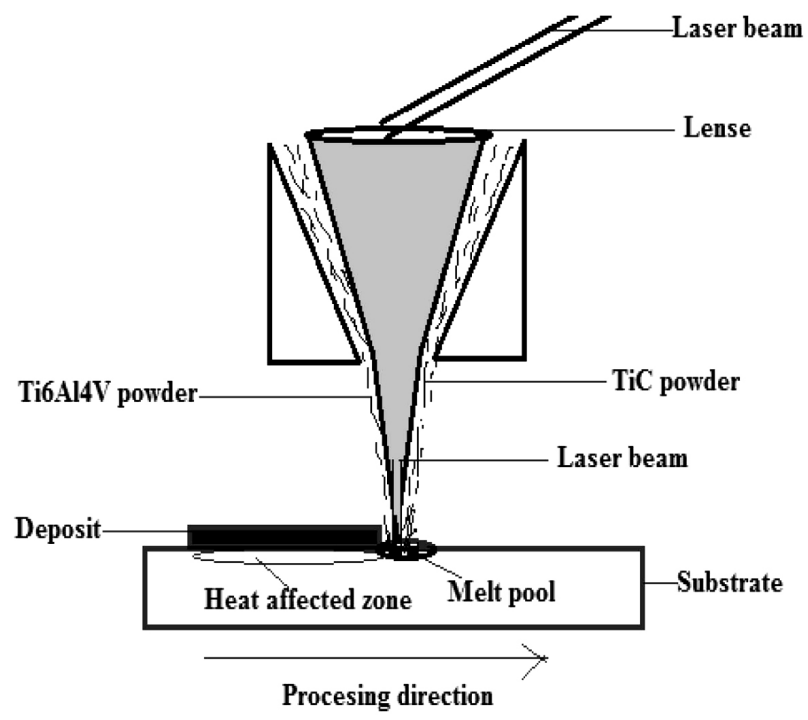

Figure 2: The schematic diagram of laser metal deposition process ${ }^{14}$ Slika 2: Shematski prikaz postopka laserskega nanašanja kovine ${ }^{14}$ 
performed according to the ASTM G133 - 05(2010) standard. ${ }^{13}$ The schematical diagram of the laser metal deposition process is based on R. M. Mahamood et al. ${ }^{14}$

Table 1: Chemical composition of the Ti6Al4V substrate, Ti6Al4V powder and $\mathrm{TiC}$ powder

Tabela 1: Kemijska sestava podlage iz Ti6Al4V, Ti6Al4V prahu in TiC prahu Ti6Al4V substrate

\begin{tabular}{|c|c|c|c|c|c|c|c|c|}
\hline Element & $\mathrm{Al}$ & V & $\mathrm{Fe}$ & $\mathrm{C}$ & $\mathrm{N}_{2}$ & $\mathrm{H}_{2}$ & $\mathrm{O}_{2}$ & $\mathrm{Ti}$ \\
\hline$w / \%$ & 6.42 & 3.91 & 0.19 & 0.00 & 0.00 & 0.004 & 0.155 & balance \\
\hline \multicolumn{9}{|c|}{ Ti6A14V powder } \\
\hline Element & $\mathrm{Al}$ & V & $\mathrm{Fe}$ & $\mathrm{C}$ & $\mathrm{N}_{2}$ & $\mathrm{H}_{2}$ & $\mathrm{O}_{2}$ & $\mathrm{Ti}$ \\
\hline$w / \%$ & 6.20 & 3.90 & 0.18 & 0.00 & 0.005 & 0.005 & 0.150 & balance \\
\hline \multicolumn{9}{|c|}{ TiC Powder } \\
\hline Element & $\mathrm{C}$ & $\mathrm{O}_{2}$ & $\mathrm{~N}$ & & $\mathrm{Fe}$ & $\mathrm{Al}$ & $\mathrm{Na}$ & $\mathrm{Ti}$ \\
\hline$w / \%$ & 19.5 & 0.28 & 0. & & 045 & 0.03 & 0.026 & balance \\
\hline
\end{tabular}

\section{RESULTS AND DISCUSSION}

The morphologies of the Ti6Al4V and TiC powders are shown in Figures 3a and $\mathbf{3 b}$ respectively. The micrograph of the Ti6Al4V substrate is shown in Figure 3c. The Ti6Al4V powder is characterized by spherically shaped powder particles, which is typical of a gas-atomized powder. ${ }^{15}$ Spherically shaped, gas-atomized powder is more favoured in the laser metal deposition process because of its improved absorption of the laser rays. ${ }^{15}$ The TiC powder is a ball-milled powder with an irregular shape, which is the characteristics of any ball-milled powder. The Ti6Al4V substrate is characte-
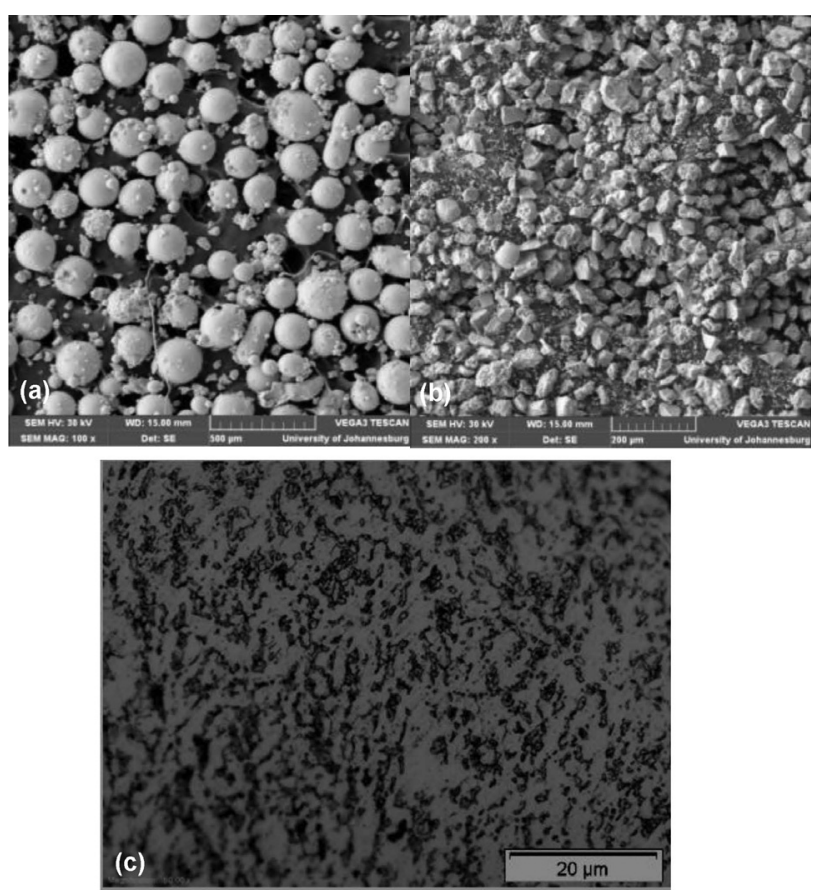

Figure 3: a) Morphology of the Ti6Al4V powder, b) morphology of the TiC powder, c) micrograph of the Ti6Al4V substrate

Slika 3: a) Morfologija prahu Ti6Al4V, b) morfologija prahu TiC, c) mikrostruktura podlage iz Ti6Al4V rized by alpha (light contrast) and beta (dark contrast) phases, as shown in Figure 3c.

The results of the intermetallic of $\mathrm{Ti}_{3} \mathrm{Al}$ (in percentage), the average Vickers hardness number and the wear-volume loss are presented in Table 2.

Table 2: Results

Tabela 2: Rezultati

\begin{tabular}{|c|c|c|c|c|}
\hline $\begin{array}{c}\text { Sample } \\
\text { designation }\end{array}$ & $\begin{array}{c}\text { Scanning } \\
\text { speed }(\mathrm{m} / \mathrm{s})\end{array}$ & $\begin{array}{c}\mathrm{Ti}_{3} \mathrm{Al} \\
(\%)\end{array}$ & $\begin{array}{c}\text { Average Vi- } \\
\text { ckers hardness } \\
\text { number }\end{array}$ & $\begin{array}{c}\text { Wear } \\
\text { volume } \\
\left(\mathrm{mm}^{3}\right)\end{array}$ \\
\hline $\mathrm{A}$ & 0.015 & 5 & 386 & 0.098 \\
\hline $\mathrm{B}$ & 0.025 & 6 & 390 & 0.082 \\
\hline $\mathrm{C}$ & 0.035 & 8 & 420 & 0.08 \\
\hline $\mathrm{D}$ & 0.045 & 12 & 448 & 0.07 \\
\hline $\mathrm{E}$ & 0.055 & 13 & 449 & 0.061 \\
\hline $\mathrm{F}$ & 0.065 & 15 & 460 & 0.058 \\
\hline $\mathrm{G}$ & 0.075 & 12 & 469 & 0.071 \\
\hline $\mathrm{H}$ & 0.085 & 10 & 475 & 0.086 \\
\hline $\mathrm{I}$ & 0.095 & 5 & 489 & 0.082 \\
\hline J & 0.105 & 4 & 498 & 0.1 \\
\hline Substrate & 0 & 0 & 300 & 0.178 \\
\hline
\end{tabular}

The graph of the $\mathrm{Ti}_{3} \mathrm{Al}$ intermetallic against the scanning speed is shown in Figure 4a. The graph of the average Vickers hardness against the scanning speed is shown in Figure $\mathbf{4 b}$. The wear volume is plotted against the scanning speed and is shown in Figure 4c. The combined graph of the $\mathrm{Ti}_{3} \mathrm{Al}$ intermetallic and the wear volume is shown in Figure 4d. The $\mathrm{Ti}_{3} \mathrm{Al}$ intermetallic
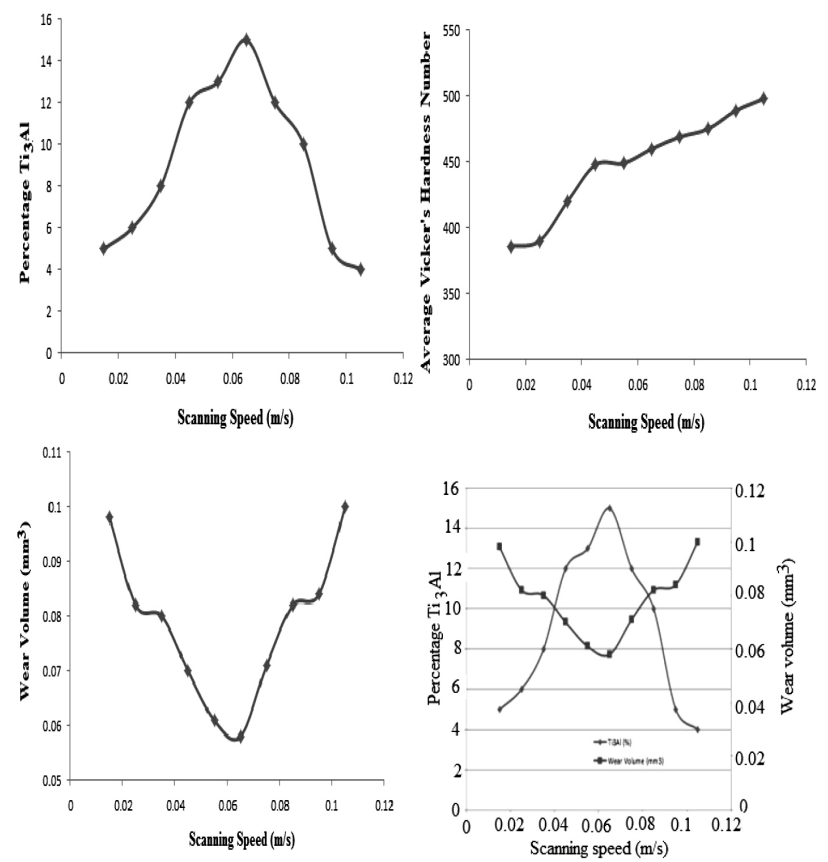

Figure 4: Graph of scanning speed and: a) percentage $\mathrm{Ti}_{3} \mathrm{Al}$, b) average Vickers hardness, c) wear volume, d) percentage $\mathrm{Ti}_{3} \mathrm{Al}$ and wear volume

Slika 4: Diagrami odvisnosti hitrosti skeniranja in: a) odstotka Ti3 Al, b) povprečne trdote po Vickersu, c) volumna obrabe, d) odstotka $\mathrm{Ti}_{3} \mathrm{Al}$ in volumna obrabe 
was found to increase as the scanning speed was initially increased. The maximum $\mathrm{Ti}_{3} \mathrm{Al}$ intermetallic was seen at a scanning speed of $0.065 \mathrm{~m} / \mathrm{s}$ with a value of $15 \%$. As the scanning speed was increased beyond $0.065 \mathrm{~m} / \mathrm{s}$, the $\mathrm{Ti}_{3} \mathrm{Al}$ intermetallic was seen to start decreasing. Our earlier study also revealed that as the scanning speed was increased, the wear resistance was found to be increased and then decrease as the scanning speed was further increased. The reason for this was attributed to the unmelted carbide (UMC) particles, whose size and quantity were found to be responsible for the wear behaviour of the laser metal deposited TiC/Ti6Al4V composite. ${ }^{16}$ The present investigation shows that it was not only the unmelted carbide particles that were responsible for the wear-resistance behaviour, the $\mathrm{Ti}_{3} \mathrm{Al}$ intermetallic formed also contributed to it. The XRD analysis (Figure 5) revealed that the $\mathrm{Ti}_{3} \mathrm{Al}$ intermetallic was changing with the change in the scanning speed, and it is also found to have an effect on the wear-resistance behaviour, as shown in Figure 4a. The higher quantity of $\mathrm{Ti}_{3} \mathrm{Al}$ intermetallic was seen to improve the wear resistance behaviour of the $\mathrm{TiC} / \mathrm{Ti} 6 \mathrm{Al} 4 \mathrm{~V}$ composites. The $\mathrm{Ti}_{3} \mathrm{Al}$ intermetallic is formed as a result of the solid-state phase transformation of the primary $\alpha$ phase structure at a low scanning speed. At a low scanning speed, the laser material interaction time is longer and the melt pool created is larger, thereby causing the solidification and cooling time to be longer and thus allowing a small quantity of the $\mathrm{Ti}_{3} \mathrm{Al}$ to be formed. As the scanning speed was increased, the laser material interaction time was reduced and the melt pool produced is smaller. This
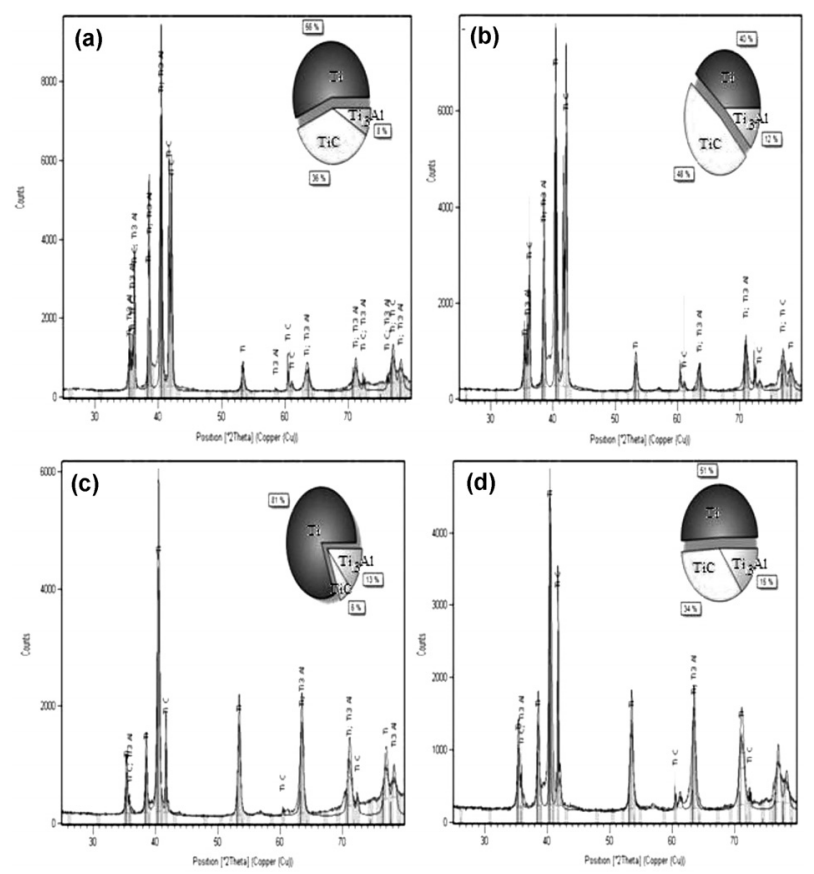

Figure 5: The XRD analysis of the sample at the scanning speed of: a) $0.035 \mathrm{~m} / \mathrm{s}$, b) $0.045 \mathrm{~m} / \mathrm{s}$, c) $0.055 \mathrm{~m} / \mathrm{s}$, d) $0.065 \mathrm{~m} / \mathrm{s}$

Slika 5: Rentgenogram vzorca pri hitrosti skeniranja: a) $0,035 \mathrm{~m} / \mathrm{s}$, b) $0,045 \mathrm{~m} / \mathrm{s}$, c) $0,055 \mathrm{~m} / \mathrm{s}$ in d) $0,065 \mathrm{~m} / \mathrm{s}$ promotes the rapid solidification and the cooling rate of the melt pool that favours a larger quantity of $\mathrm{Ti}_{3} \mathrm{Al}$ being formed. As the scanning speed was further increased beyond $0.065 \mathrm{~m} / \mathrm{s}$, the percentage $\mathrm{Ti}_{3} \mathrm{Al}$ was found to be reduced. This may be because of improper melting of the TiC powder at these higher scanning speeds. If the scanning speed is too large, the laser material interaction time will be very short and this may result in improper melting of the powders. Also, because the melt pools created at such high scanning speeds are very small, this will result in the formation of a small quantity of the $\mathrm{Ti}_{3} \mathrm{Al}$ intermetallic. Since intermetallic compounds are produced from the solid-state reaction of the solidified melted powders and if the quantity of the melted powder is reduced as a result of high scanning speeds, it follows that the quantity of the $\mathrm{Ti}_{3} \mathrm{Al}$ intermetallic formed will be reduced. On the other hand, the microhardness was found to continue to increase as the scanning speed was increased, as shown in Figure $\mathbf{4 b}$. This is because of the insufficient melting of the $\mathrm{TiC}$ powder particles as a result of the low laser material interaction time that resulted in the production of larger unmelted carbide particles. The increase in the microhardness values even at much higher scanning speeds may be as a result of these unmelted carbide particles. The large particles of the unmelted TiC carbide are detrimental to the wear-resistance properties and that is why the wear resistance properties are found to be reducing as the scanning speed was increased beyond $0.065 \mathrm{~m} / \mathrm{s}$. The large unmelted $\mathrm{TiC}$ particles cause damage to the



Figure 6: SEM micrograph of the sample at: a) $0.025 \mathrm{~m} / \mathrm{s}$, b) higher magnification of sample in a), c) $0.065 \mathrm{~m} / \mathrm{s}$, d) higher magnification of sample in c)

Slika 6: SEM-posnetek vzorca pri: a) $0,025 \mathrm{~m} / \mathrm{s}$, b) vzorec a) pri večji povečavi, c) $0,065 \mathrm{~m} / \mathrm{s}$, d) vzorec c) pri večji povečavi 
sliding surface as a result of the cutting and tearing actions of these large unmelted $\mathrm{TiC}$ particles during the rubbing actions.

Also, as shown in a previous study, as the scanning speed was increased, the size and the quantity of the unmelted TiC particles also increased, which formed a powder lubricant that inhibits the wear action as the sliding action progresses. ${ }^{16}$ The $\mathrm{Ti}_{3} \mathrm{Al}$ also mimics the behaviour of the unmelted carbide action as it is also hard and brittle, which also forms a powder lubricant as the sliding wear action continues, due to rubbing and grinding of the $\mathrm{Ti}_{3} \mathrm{Al}$ and the unmelted carbide particles (Figue 6) as the wear action continues. The particle size of these $\mathrm{Ti}_{3} \mathrm{Al}$ intermetallic and the smaller unmelted $\mathrm{TiC}$ carbide particles are reduced in size as they are rubbed against one another during the wear experiment. This unmelted $\mathrm{TiC}$ and the $\mathrm{Ti}_{3} \mathrm{Al}$ intermetallic particles were ground by the rubbing surfaces of the deposited sample and the tungsten carbide ball to form fine powder. The fine powder now forms a protective layer between the rubbing surfaces, which prevents the two surfaces from being in contact, thereby forming a powdery lubricant between the two surfaces and thus, reducing the wear action.

The wear track of the parent material is shown in Figure 7a. It is characterized by parallel ploughing grooves, as shown in Figure 7a, and their formation is as a result of the combination of abrasive wear, adhesive wear and plastic deformation. ${ }^{16}$ The wear tracks of the


Figure 7: SEM micrograph of the wear track of the: a) substrate ${ }^{16}$, b) sample at the scanning speed of $0.015 \mathrm{~m} / \mathrm{s}, \mathrm{c}$ ) sample at the scanning speed of $0.065 \mathrm{~m} / \mathrm{s}$, d) sample at the scanning speed of $0.105 \mathrm{~m} / \mathrm{s}$

Slika 7: SEM-posnetek sledi obrabe na: a) podlagi ${ }^{16}$, b) vzorec pri hitrosti skeniranja $0,015 \mathrm{~m} / \mathrm{s}$, c) vzorec pri hitrosti skeniranja 0,065 $\mathrm{m} / \mathrm{s}, \mathrm{d}$ ) vzorec pri hitrosti skeniranja $0,105 \mathrm{~m} / \mathrm{s}$ samples at $0.015 \mathrm{~m} / \mathrm{s}$ are shown in Figure $7 \mathbf{b}$, while that of the sample at a scanning speed of $0.065 \mathrm{~m} / \mathrm{s}$ is shown in Figure 7c and the wear track of the sample at the scanning speed of $0.105 \mathrm{~m} / \mathrm{s}$ is shown in Figure 7d. At a low scanning speed, the UMC and the $\mathrm{Ti}_{3} \mathrm{Al}$ seen in the microstructure are less than those seen at the higher scanning speed. Both the UMC and the $\mathrm{Ti}_{3} \mathrm{Al}$ serve as reinforcement in the composite. The smaller number of these reinforcements does not really improve the wear resistance because they are serving as a third-body wear mechanism that results in cutting of the surfaces in sliding motion, as seen in Figure $\mathbf{7 b}$. The size of the UMC is smaller at a scanning speed of $0.065 \mathrm{~m} / \mathrm{s}$ when compared to those seen at higher scanning speeds. Also, the quantities of the UMC are more than those seen at a lower scanning speed, where most of the $\mathrm{TiC}$ powder is completely melted. The quantity of the $\mathrm{Ti}_{3} \mathrm{Al}$ is also more at the scanning speed of $0.065 \mathrm{~m} / \mathrm{s}$, thereby resulting in improved wear-resistance behaviour (Figure 7c). This is because the UMC particles and the $\mathrm{Ti}_{3} \mathrm{Al}$ are ground into finer powder as the sliding action progresses because they are hard and brittle. The powder they form serves as a protective layer (and as powder lubricant), which tends to reduce the wear action of the two surfaces in the sliding motion. The size of the UMC particles seen at the scanning speed of $0.105 \mathrm{~m} / \mathrm{s}$ is larger than those seen at the lower scanning speed because of the lower laser material interaction time at the higher scanning speed. There was not enough time to melt the surfaces of the TiC powder particles at the higher scanning speed, thereby leaving behind larger UMC TiC particles. Also, the quantity of the UMC TiC particles as well as the $\mathrm{Ti}_{3} \mathrm{Al}$ intermetallic is fewer than those seen at the scanning speed of $0.065 \mathrm{~m} / \mathrm{s}$. These large UMC TiC particles cause cracking of the surfaces in the sliding motion, thereby escalating the wear action as shown in Figure 7d.

\section{CONCLUSION}

A study of the influence of the scanning speed on an $\mathrm{Ti}_{3} \mathrm{Al}$ intermetallic produced in-situ during a laser metal deposition process has been conducted. The scanning speed was varied between $0.015 \mathrm{~m} / \mathrm{s}$ and $0.105 \mathrm{~m} / \mathrm{s}$. The evolving microstructures were studied; microhardness and wear test were also performed. The effect of the quantity of the $\mathrm{Ti}_{3} \mathrm{Al}$ on the wear-resistance property was investigated. Qualitative metallographic analyses of the microstructures confirmed that during the solidification and cooling processes of the deposited samples, the Ti6Al4V and the TiC powders were transformed into various phases, including the intermetallic phase of $\mathrm{Ti}_{3} \mathrm{Al}$. Also, the secondary phase of $\mathrm{Ti}_{3} \mathrm{Al}$ is formed in-situ by chemical reactions between the Ti6Al4V and the TiC. The intensive phase transformations that occurred, during the solidification and cooling down process, resulted in the various quantities of the $\mathrm{Ti}_{3} \mathrm{Al}$ 


\section{R. M. MAHAMOOD, E. T. AKINLABI: INFLUENCE OF SCANNING SPEED ON THE INTERMETALLIC ...}

produced, which was found to initially increase as the scanning speed was increased and then reduce as the scanning speed was further increased. The wear test conducted revealed that the wear-resistance property initially increased as the scanning speed was increased and then decreased as the scanning speed was increased beyond $0.065 \mathrm{~m} / \mathrm{s}$. Also, the maximum $\mathrm{Ti}_{3} \mathrm{Al}$ observed also occurred at the same scanning speed and it was found to be $15 \%$. It can be concluded that, the optimum scanning speed for the best wear-resistance performance of the laser metal deposited Ti6Al4V and TiC composite is $0.065 \mathrm{~m} / \mathrm{s}$ for the set of other processing parameters considered in this study.

\section{Acknowledgments}

This work is supported by L'Oreal UNESCO for Women in Science and the University of Johannesburg Research Council.

\section{REFERENCES}

${ }^{1}$ C. H. J. Hager, J. H. Sanders, S. Sharma, Unlubricated gross slip fretting wear of metallic plasma-sprayed coatings for Ti6Al4V surfaces, Wear, 3/4 (2008) 265, 439-451

${ }^{2}$ W. Pang, H. C. Man, T. M. Yue, Laser surface coating of Mo-WC metal matrix composite on Ti6A14V alloy, Materials Science and Engineering A, 1/2 (2005) 390, 144-153

${ }^{3}$ F. Variola, J. H. Yi, L. Richert, J. D. Jwues, F. Rosei, A. Nanci, Tailoring the surface properties of Ti6Al4V by controlled chemical oxidation, Biomaterials, 10 (2008 ) 29, 1285-1298

${ }^{4}$ M. M. Silva, M. Ueda, L. Pichon, H. Reuther, C. M. Lepienski, Surface modification of Ti6Al4V alloy by PIII at high temperatures: Effects of plasma potential, Nuclear Instruments and Methods in Physics Research B, 1/2 (2007) 257, 722-726

${ }^{5}$ J. Scott, N. Gupta, C. Wember, S. Newsom, T. Wohlers, T. Caffrey, Additive manufacturing: status and opportunities, Science and
Technology Policy Institute, (2012), https://www.ida.org/stpi/ occasionalpapers/papers/AM3D_33012_Final.pdf

${ }^{6}$ C. Li-Fang, Z. Yong-Zhong, S. Li-Kai, Microstructure and formation mechanism of titanium matrix composites coating on Ti-6Al-4V by laser cladding, Rare Metals, 4 (2007) 26, 342-346

${ }^{7}$ J. D. Majumdar, I. Manna, A. Kumar, Direct laser cladding of Co on Ti-6Al-4V with a compositionally graded interface, Journal of Materials Processing Technology, 209 (2009), 2237-2243

${ }^{8}$ R. Mahmoodian, M. A. Hassan, M. Hamdi, R. Yahya, R.G. Rahbari, In situ $\mathrm{TiC}-\mathrm{Fe}-\mathrm{A} 12 \mathrm{O} 3-\mathrm{TiAl} / \mathrm{Ti} \mathrm{Al}$ composite coating processing using centrifugal assisted combustion synthesis, Composites Part B: Engineering, 59 (2014), 279-28

${ }^{9}$ Z. Liu, X. Zhang, F. Xuan, Z. Wang, S. Tu, Effect of laser power on the microstructure and mechanical properties of $\mathrm{TiN} / \mathrm{Ti}_{3} \mathrm{Al}$ composite coatings on Ti6Al4V, Chinese Journal of Mechanical Engineering, 26 (2013) 4, 714-721

${ }^{10}$ B. G. Guo, J. S. Zhou, S. T. Zhang, H. D. Zho, Y. P. Pu, J. M. Chen, Microstructure and tribological properties of in situ synthesized TiN/Ti3Al intermetallic matrix composite coatings on titanium by laser cladding and laser nitriding. Mater Science Engineering A, 480 (2008), 404-10

${ }^{11}$ E3-11 (2011). Standard Guide for Preparation of Metallographic Specimens, ASTM international Book of Standards, vol. 03.01

${ }^{12}$ ASTM E384 - 11e1, 2011, Standard Test Method for Knoop and Vickers Hardness of Materials, ASTM International Book of Standards, vol. 03.01

${ }^{13}$ ASTM G133 - 05, 2010, Standard Test Method for Linearly Reciprocating Ball-on-Flat Sliding Wear, ASTM International Book of Standards, vol. 03.02

${ }^{14}$ R. M. Mahamood, E. T. Akinlabi, M. Shukla, S. Pityana, Characterization of Laser Deposited Ti6A4V/TiC Composite. Lasers in Engineering, 29 (2014) 3-4, 197-213

${ }^{15}$ C. T. Schade, T. F. Murphy, Chris Walton, Development Of Atomized Powders for Additive Manufacturing, Powder Metallurgy Word Congress, (2014). Accessed on $2^{\text {nd }}$ July 2014 available at: http://www.gkn.com/hoeganaes/media/Tech\%20Library/Schade-Ato mized $\% 20$ Powders $\% 20$ for $\% 20$ Additive $\% 20$ Manufacturing $\% 20 \% 28$ $1 \% 29 . p d f$

${ }^{16}$ R. M. Mahamood, E. T. Akinlabi, M. Shukla and S. Pityana, Scanning Velocity Influence on Microstructure, Microhardness and Wear Resistance Performance on Laser Deposited Ti6A14V/TiC Composite, Materials and Design, 50 (2013), 656-666 